\title{
Redescription and taxonomical considerations about Aonchotheca (Aonchotheca) pulchra n. comb. (Enoplida: Trichuridae), a nematode of Nyctinomops spp.
}

Redescrição e consideraçóes taxonômicas sobre Aonchotheca (Aonchotheca) pulchra n. comb. (Enoplida: Trichuridae), um nematódeo de Nyctinomops spp.

Daniel Fontana Ferreira Cardia ${ }^{1,2 *}$; Estevam Guilherme Lux Hoppe ${ }^{3}$; José Hairton Tebaldi ${ }^{3}$; Felipe Fornazari ${ }^{4}$; Benedito Donizete Menozzi ${ }^{4}$; Helio Langoni ${ }^{4}$; Adjair Antônio do Nascimento ${ }^{3}$; Katia Denise Saraiva Bresciani ${ }^{5}$

\begin{abstract}
${ }^{1}$ Curso de Medicina Veterinária, Centro Universitário de Rio Preto - UNIRP, São José do Rio Preto, SP, Brasil
${ }^{2}$ Programa de Pós-graduação em Medicina Veterinária, Faculdade de Ciências Agrárias e Veterinárias - FCAV, Universidade Estadual Paulista - UNESP, Jaboticabal, SP, Brasil

${ }^{3}$ Departamento de Medicina Veterinária Preventiva e Reproduçáo Animal, Faculdade de Ciências Agrárias e Veterinárias - FCAV, Universidade Estadual Paulista - UNESP, Jaboticabal, SP, Brasil

${ }^{4}$ Departamento de Higiene Veterinária e Saúde Pública, Faculdade de Medicina Veterinária e Zootecnia - FMVZ, Universidade Estadual Paulista - UNESP, Botucatu, SP, Brasil

${ }^{5}$ Departamento de Apoio, Produção e Saúde Animal, Faculdade de Medicina Veterinária - FMVA, Universidade Estadual Paulista UNESP, Araçatuba, SP, Brasil
\end{abstract}

Received April 9, 2014

Accepted July 11, 2014

\begin{abstract}
Pterothominx pulchra (Freitas, 1934) are little known gastric nematodes of Nyctinomops laticaudatus (Chiroptera: Molossidae). Information about the occurrence and host range of these parasites in Neotropical region is still scanty, and the only two morphological descriptions available in the literature are divergent about the presence or absence of a spiny spicular sheath in males, which may lead to incorrect taxonomical positioning, since this feature represents the main difference between the genera Pterothominx and Aonchotheca. Based on the absence of this morphological feature in specimens of this nematode obtained from N. laticaudatus and Nyctinomops macrotis bats captured in two municipalities in the state of São Paulo, Brazil, the present study reclassifies the aforementioned species in the genus Aonchotheca and allocates it to the subgenus Aonchotheca. Additional morphometric data and new host and locality records are also provided.
\end{abstract}

Keywords: Nematoda, Capillariinae, Chiroptera, Molossidae, taxonomy, morphology.

\section{Resumo}

Pterothominx pulchra (Freitas, 1934) são nematódeos gástricos pouco conhecidos de Nyctinomops laticaudatus (Chiroptera: Molossidae). Informaçôes referentes à ocorrência e variedade de hospedeiros desses parasitos ainda são escassas na regiáo Neotropical. As únicas duas descriçôes morfológicas disponíveis na literatura são divergentes entre si quanto à presença de bainha espicular espinhosa nos machos, o que resultou no posicionamento taxonômico equivocado desta espécie, uma vez que, é a principal característica para diagnóstico dos gêneros Pterothominx e Aonchotheca. Baseado na ausência dessa característica morfológica em espécimes desse nematódeo, obtidos em morcegos $N$. laticaudatus e Nyctinomops macrotis capturados em dois municípios do Estado de São Paulo, Brasil, o presente estudo classifica a referida espécie no gênero Aonchotheca e a aloca no subgênero Aonchotheca, além de fornecer dados morfométricos adicionais e novos registros de hospedeiro e localidades.

Palavras-chave: Nematoda, Capillariinae, Chiroptera, Molossidae, taxonomia, morfologia.

\footnotetext{
*Corresponding author: Daniel Fontana Ferreira Cardia, Curso de Medicina

Veterinária, Centro Universitário de Rio Preto - UNIRP, Rua Ivete Gabriel

Atique, 45, Boa Vista, CEP 15025-400, São José do Rio Preto, SP, Brasil,

e-mail: danielcardia@hotmail.com
} 


\section{Introduction}

Capillaria pulchra Freitas, 1934 was first described in Nyctinomops laticaudatus Geoffroy, 1805 in the municipality of Rio de Janeiro, Brazil (Freitas, 1934). Later, Lent et al. (1946) redescribed this nematode in the city of Asunción, Paraguay, adding several morphometric characteristics that were omitted in the original description. These authors also corrected some mistakes in morphological data presented by Freitas (1934), including the erroneous description of the presence of spiny spicular sheath in males, since this morphological feature was not observed in the newly collected specimens or in the type specimens (Lent et al., 1946).

López-Neyra (1947, apud Vicente et al., 1997, p. 29) transferred this species to the genus Echinocoleus López-Neyra, 1947 and, later, the nematode was placed in the genus Thominx Dujardin, 1845 by Skrjabin and Shikhobalova (1954, apud Vicente et al., 1997, p. 29). Finally, Moravec (1982) classified the parasite in the genus Pterothominx Freitas, 1959, which has, as one of its main morphological features, the presence of a spiny spicular sheath. Thus, the latter classification proposed by Moravec (1982) was based on the original description of this species, compromising its taxonomic position, which remains incorrect to this date.

Based on the morphological analyses of new specimens collected from $N$. laticaudatus and Nyctinomops macrotis Gray, 1840 in the state of São Paulo, Brazil, we propose a new taxonomic arrangement for this Capillariinae, along with new host and locality records. Morphological and morphometric data are also presented. Thus, the present study contributes to a better knowledge of the helminth fauna of Neotropical bats, which it is still very scanty, despite the richness of chiropteran fauna in this region.

\section{Materials and Methods}

Eight $N$. laticaudatus and one $N$. macrotis bats were necropsied. These animals had been previously collected between 2008 and 2010 in urban areas by the state's public disease control services and were frozen at $-20{ }^{\circ} \mathrm{C}$ until the moment of analysis. All the procedures adopted in this study were approved by the Animal Ethics Committee of FCAV/UNESP (Process 001128/11).

The necropsies were performed under an Opton ${ }^{\circledast}$ stereoscopic microscope, aided by ophthalmic surgical instruments. After a detailed examination of all the viscera, the parasites were fixed and preserved in $70 \%$ ethanol, in properly identified conical microtubes. Later, these nematodes were clarified in $80 \%$ glacial acetic acid for morphological evaluation.

The species description was based on the characteristics of all the mature specimens analyzed, comprising seven males and four females. Measurements of morphological characteristics were expressed in millimeters, as mean \pm standard deviation. Morphometric studies were performed using Image Pro Plus v. 4.0 image analysis software, with images recorded with a QColor 3 digital camera attached to an Olympus BX-51 microscope. Illustrations were made in a Carl-Zeiss ${ }^{\circledast}$ microscope equipped with a camera lucida. The descriptors of infection are in accordance with Bush et al. (1997).
The taxonomic identification of this species was based on reports by Freitas (1934), Freitas and Lent (1936), Lent et al. (1946), Moravec (1982), Baruš and Sergejeva (1990), Anderson et al. (2009) and Gibbons (2010).

\section{Results}

Aonchotheca (Aonchotheca) pulchra (Freitas, 1934) n. comb. Redescription

General. Enoplida: Trichinelloidea, Trichuridae, Capillariinae. Whitish filiform nematodes before and after fixation. Delicate longitudinal and transversal cuticle striations along the body length. Cephalic region tapered and rounded. Circular oral opening without lips. Esophagus long, with a single row of visible stichocytes surrounded by two lateral bacillary bands.

Males. Body length $12.55 \pm 0.44$, body width $0.07 \pm 0.01$ at esophageal-intestinal junction. Elongated esophagus $4.48 \pm 0.14$ long. Nerve ring $0.11 \pm 0.03$ distant from anterior ending. Subterminal cloacal opening, with four papillae grouped in two pairs near the cloacal opening, and another pair of terminal papillae at the tail tip. A thin and well developed membrane in the male tail. Part of the caudal membrane arranged as lateral alae. The other part united the cloacal and terminal papillae (Figure 1 A-C). The spicule indistinct due to little or no sclerotization. The rugged non-spiny spicular sheath generally protruded outside the body and curled (Figure 1C).

Females. Body length $15.25 \pm 2.42$, body width $0.08 \pm 0.01$ at esophageal-intestinal junction. Elongated esophagus $5.59 \pm 0.84$ long. Nerve ring $0.20 \pm 0.06$ distant from anterior ending. The vulvar opening at $0.07 \pm 0.02$ from the esophagealintestinal junction. Vulvar appendage well developed, with $0.04 \pm 0.01$ length, and $0.02 \pm 0.01$ width. The vagina $0.27 \pm 0.03$ long, with strong muscular walls (Figure 1D). Eggs typically bioperculate, with $0.04 \pm 0.01$ length and $0.02 \pm 0.01$ width. Conical tail, slightly curved ventrally (Figure 1E). Subterminal anus, $0.01 \pm 0.01$ distant from tail tip.

\section{Taxonomic summary}

Type host: Nyctinomops laticaudatus Geoffroy, 1805.

Other host: Nyctinomops macrotis Gray, 1840.

Site of infection: Stomach mucosa.

Prevalence and mean intensity: Three of eight $N$. laticaudatus $(35.5 \%)$ and in a single necropsied $N$. macrotis (100\%); 2.75 (1-5) worms per host.

Type locality: municipality of Rio de Janeiro, state of Rio de Janeiro, Brazil.

Other localities: municipality of Asunción, Paraguay (LENT et al., 1946); municipality of Botucatu (22 $52^{\prime} 47^{\prime \prime} \mathrm{S}$ and $\left.48^{\circ} 26^{\prime} 42^{\prime \prime} \mathrm{W}\right)$ and municipality of Dois Córregos (22 21' $58^{\prime \prime}$ $S$ and $48^{\circ} 22^{\prime} 49^{\prime}$ W), state of Sáo Paulo, Brazil (present study).

Specimens deposited: Male and female vouchers, collected from $N$. laticaudatus, were deposited in the Helminthological Collection of the Oswaldo Cruz Institute in Rio de Janeiro, RJ, Brazil, under collection number CHIOC 35824. Other vouchers were deposited at the Laboratory of Parasitic Diseases, Department of Production and Animal Health, Faculty of Veterinary Medicine, UNESP, in Araçatuba, SP, Brazil. 

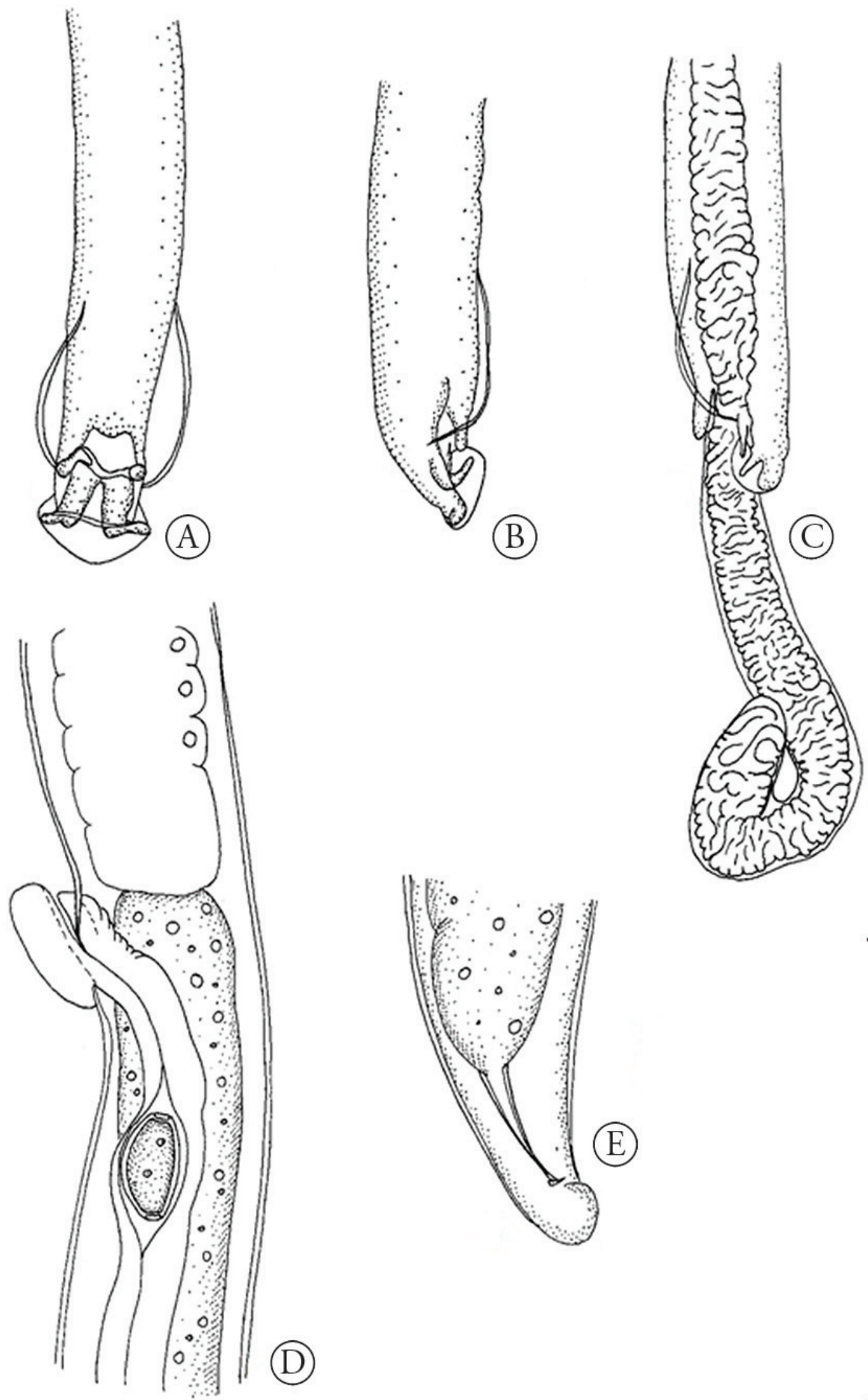

(D)

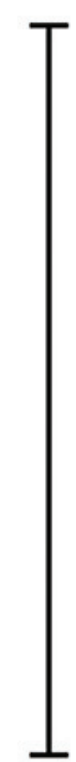

Figure 1. Aonchotheca (Aonchotheca) pulchra (Freitas, 1934) n. comb. Male posterior portion, ventral view (A). Male posterior portion, lateral view (B). Male anterior portion with protruding, non-spiny spicular sheath, lateral view (C). Vulvar region, lateral view (D). Female posterior portion, lateral view (E). Scale bars $20 \mu \mathrm{m}$. 


\section{Remarks}

Aonchotheca (Aonchotheca) pulchra n. comb. differs markedly from three congeneric species of intestinal parasites of Neotropical bats, which have been described only in Brazil, such as Aonchotheca pintoi (Freitas, 1934) Moravec, 1984, parasitizing "Chiroptera" (FREITAS, 1934; MORAVEC, 1982), Aonchotheca pereirai (Freitas and Lent, 1936) Moravec, 1982 (FREITAS; LENT, 1936; MORAVEC, 1982), obtained from "Molossidae", and Aonchotheca parca Freitas and Dobbin Jr, 1961 (FREITAS; DOBBIN Jr, 1961), found parasitizing Glossophaga soricina Pallas, 1766. The male morphology (fundamentally, number and position of papillae in the tail) and morphometric data of both sexes (essentially, body and esophagus length) are sufficient to separate these species.

\section{Discussion and Conclusions}

The specimens under study showed morphometric data and morphological features compatible with those of $P$. pulchra, but the present study presents further information on the tail morphology of the male specimens. In addition, like Lent et al. (1946), we did not observe a characteristic spiny spicular sheath in the analyzed males. As the presence of this specific type of spicular sheath is fundamental to classification in the genus Pterothominx (MORAVEC, 1982; BARUŠ; SERGEJEVA, 1990; GIBBONS, 2010), we propose the reallocation of this species to the genus Aonchotheca López-Neyra, 1947, which differs from the former by the absence of this morphological feature. Additionally, species of the genus Aonchotheca may be separated from other Capillariinae by the presence of non-ventrally oriented lateral caudal alae and a membranous bursa supported by one or more pairs of lateral projections (GIBBONS, 2010). Furthermore, because this species parasitizes mammals such as Nyctinomops spp. bats, it can be allocated to the subgenus Aonchotheca, according to Gibbons (2010). Also, N. macrotis represents a new host record, and the state of Sáo Paulo a new locality for this nematode in Brazil.

\section{Acknowledgments}

The authors wish to thank the anonymous reviewers for their constructive comments and suggestions.

\section{References}

Anderson RC, Chabaud AG, Willmott S. Keys to the Nematode Parasites of Vertebrates. Archival Volume. Wallingford: CABI Publishing; 2009.

Baruš V, Sergejeva TP. Capillariids parasitic in birds in the Palaearctic region (4). Genera Pterothominx and Aonchotheca. Acta Sc Nat Brno. 1990; 24(12): 1-48.

Bush AO, Lafferty KD, Lotz JM, Shostak AW. Parasitology meets ecology on its own terms: Margolis et al. revisited. J Parasitol. 1997; 83(4): 575 583. http://dx.doi.org/10.2307/3284227. PMid:9267395

Freitas JFT. Sobre as espécies do gênero Capillaria Zeder, 1800, parasitas de morcegos. Mem Inst Oswaldo Cruz. 1934; 28(2): 239-245. http:// dx.doi.org/10.1590/S0074-02761934000200004.

Freitas JFT, Dobbin JE Jr. Aonchoteca parca sp. nov., nematódeo capilariineo parasito de quiroptero. Atas Soc Biol. 1961; 5(4): 21-22.

Freitas JFT, Lent H. Estudo sobre os Capillariinae parasitos de mamíferos (Nematoda: Trichuroidea). Mem Inst Oswaldo Cruz. 1936; 31(1): 85-160.

Gibbons LM. Keys to the Nematode Parasites of Vertebrates. Supplementary Volume. Wallingford: CABI Publishing; 2010.

Lent H, Freitas JFT, Proença MC. Algunos nemátodos de murciélagos coleccionados en el Paraguay. Rev Bras Biol. 1946; 6(4): 485-497.

Moravec F. Proposal of a new systematic arrangement of nematodes of the family Capillariidae. Folia Parasitol (Praha). 1982; 29(2): 119-132. PMid:7106653.

Vicente JJ, Rodrigues HO, Gomes DC, Pinto RM. Nematóides do Brasil. Parte V: Nematóides de mamíferos. Rev Bras Zool 1997; 14(S1):8-29. 